\title{
Human pregnane $X$ receptor is expressed in breast carcinomas, potential heterodimers formation between hPXR and RXR-alpha
}

\author{
Isabel Conde ${ }^{1,4}$, María VT Lobo ${ }^{1}$, Javier Zamora ${ }^{2}$, Julio Pérez ${ }^{1}$, \\ Francisco J González ${ }^{3}$, Emilio Alba ${ }^{3}$, Benito Fraile ${ }^{1}$, Ricardo Paniagua ${ }^{1}$ and \\ María I Arenas*1
}

Address: ${ }^{1}$ Department of Cell Biology and Genetics, University of Alcalá, 28871 Alcalá de Henares, Madrid, Spain, ${ }^{2}$ Clinical Biostatistics Unit, Hospital Ramón y Cajal, CIBER Epidemiología y Salud Pública (CIBERESP), 28034 Madrid, Spain, 32Department of Medical Oncology, Hospital Universitario Virgen de la Victoria, 3091, 29010 Málaga, Spain and ${ }^{4}$ Department of Cellular and Molecular Physiopathology, Centro de Investigaciones Biológicas, CSIC, 28040 Madrid, Spain

Email: Isabel Conde - iconde@cib.csic.es; María VT Lobo - mval.toledo@uah.es; Javier Zamora - javier.zamora@hrc.es; Julio Pérez - juliop.marquez@uah.es; Francisco J González - fjgonzalez02@yahoo.es; Emilio Alba - oncologia98@yahoo.com; Benito Fraile - benito.fraile@uah.es; Ricardo Paniagua -ricardo.paniagua@uah.es; María I Arenas* - misabel.arenas@uah.es

* Corresponding author

Published: 19 June 2008

BMC Cancer 2008, 8:174 doi:10.1/86/147|-2407-8-174
Received: 4 February 2008

Accepted: 19 June 2008

This article is available from: http://www.biomedcentral.com/147I-2407/8//74

(C) 2008 Conde et al; licensee BioMed Central Ltd.

This is an Open Access article distributed under the terms of the Creative Commons Attribution License (http://creativecommons.org/licenses/by/2.0), which permits unrestricted use, distribution, and reproduction in any medium, provided the original work is properly cited.

\begin{abstract}
Background: The human pregnane $\mathrm{X}$ receptor (hPXR) is an orphan nuclear receptor that induces transcription of response elements present in steroid-inducible cytochrome P-450 gene promoters. This activation requires the participation of retinoid $X$ receptors (RXRs), needed partners of $h P X R$ to form heterodimers. We have investigated the expression of $h P X R$ and RXRs in normal, premalignant, and malignant breast tissues, in order to determine whether their expression profile in localized infiltrative breast cancer is associated with an increased risk of recurrent disease.
\end{abstract}

Methods: Breast samples from 99 patients including benign breast diseases, in situ and infiltrative carcinomas were processed for immunohistochemistry and Western-blot analysis.

Results: Cancer cells from patients that developed recurrent disease showed a high cytoplasmic location of both hPXR isoforms. Only the infiltrative carcinomas that relapsed before 48 months showed nuclear location of hPXR isoform 2. This location was associated with the nuclear immunoexpression of RXR-alpha.

Conclusion: Breast cancer cells can express both variants I and 2 of hPXR. Infiltrative carcinomas that recurred showed a nuclear location of both hPXR and RXR-alpha; therefore, the overexpression and the subcellular location changes of hPXR could be considered as a potential new prognostic indicator.

\section{Background}

The human pregnane $\mathrm{X}$ receptor (hPXR, also known as SXR) is a member of the NR1I2 subfamily [1]. This recep- tor presents different isoforms that are differentially activated by a remarkably diverse collection of compounds including both xenobiotics and natural steroids [2]. PXR 
orthologs show marked differences in their activation profiles between species; thus, pregnenolone 16 $\alpha$-carbonitrile is an efficacious activator of mouse and rat PXR, but has much less activity on the human and rabbit receptors. Conversely, rifampicin activates the human and rabbit PXR but has no activity on the mouse or rat receptors [3].

PXR is a needed partner of RXRs [4] to form heterodimers that induce transcription from ER6 [5] or IR6 [6] response elements present in steroid-inducible cytochrome P450 (CYP) gene promoters [7]. Cytochrome P450 constitutes a multigene family of hemoproteins responsible for the metabolism of numerous xenobiotics, including therapeutic drugs, environmental chemicals and dietary constituents, as well as endogenous compounds such as steroids and bile acids [8]. Kliewer et al. [3] demonstrated in mice that the strong activation of PXR evoked by the pregnane compounds seemed to be mediated by CYP3A induction; this effect also appeared in the homologous counterparts of rat, rabbit, and humans $[5,6,9,10]$.

CYP3A and hPXR are mainly expressed in the liver and the intestine, and, to a lesser extent, in kidney and lung [11]; in addition CYP3A enzymes have been found in human breast cancer tissue $[12,13]$. The tissue distribution and the relative abundance of hPXR mRNA resemble CYP3A expression very closely, suggesting that hPXR may be important not only for induction but also for constitutive expression of these enzymes [11]. Dotzlaw et al. [14] have shown that the level of hPXR mRNA did not differ between breast tumours and their adjacent matched normal breast tissues; however, among different breast tumour types the expression of hPXR mRNA is diverse. This suggests that hPXR is not significantly altered during tumorigenesis but may display changes related to the cancer phenotype and the degree of differentiation [14]. However, Miki et al. [15] studied samples of atypical ductal hyperplasia, ductal carcinoma in situ and invasive ductal carcinoma of the human breast and they detected the presence of neither hPXR mRNA nor protein in non-neoplastic breast tissues suggesting that hPXR is predominantly expressed in carcinoma cells.

Several studies have implicated different cytochrome P450 proteins in the mechanisms of resistance to antiestrogens (tamoxifen and toremifene), taxanes and other anticancer compounds. Therefore, the study of the expression and regulatory pathways of P450 in cancer became an active research field $[16,17]$; in contrast, studies concerning hPXR are rarely found in the literature. Because $\mathrm{hPXR}$ is related to the response to different antitumoural treatments, we have investigated the distribution of this orphan receptor and its needed partner RXRs in normal, premalignant, and malignant breast tissues. Also, we analysed its relationship with the patient's clinicopathologi- cal data to elucidate whether some differences in the pattern of expression of these proteins occurred and whether these differences could be valuable for prognostic purposes.

\section{Methods \\ Patients and histological samples}

Breast samples from 99 patients randomly selected and diagnosed by the Pathology Service of the Hospital Príncipe de Asturias and Hospital Virgen de la Victoria were used with the consent of the patients and permission of the Ethics Committees of Hospitals. Glandular lesions were classified as follows: 12 cases of benign proliferative diseases (BBDs) including ductal and lobular hyperplasia, apocrine metaplasia, fibroadenoma and fibrocystic changes; 10 carcinomas in situ (CIS); 77 infiltrative carcinomas, 54 ductal (IDC) and 23 lobular (ILC). Samples were processed for immunohistochemistry (formalin fixation and paraffin embedding) and for Western blot analysis (frozen with liquid nitrogen).

All infiltrative tumour samples were classified by the TNM system; after surgery, the hormonal status of each tumour was evaluated. These patients (from 35 to 91 years of age) were diagnosed of localized breast cancer between 1998 and 2000 and they had a follow-up of 60 months. Dissection of axillary lymph nodes was carried out in all of cases. None of them received radiotherapy, hormonal therapy or chemotherapy before surgery. After immunohistochemistry and Western blot analysis, we reviewed clinical records and identified two patients' groups: Group 1) Forty five patients did not relapse after a minimum period of 24 mo. of follow-up (follow-up median 57 months, range 24 to $61 \mathrm{mo}$.). Twenty four of the 45 cases showed no evidence of ganglionar lesions at diagnosis (53.3\%) and 21 showed ganglionar metastasis (46.7\%). Group 2) Thirty two patients who relapsed with a median disease free interval of 18.5 months (range 7 to 64 mo.). Three of these 32 cases showed no ganglionar lesions at diagnosis (9.4\%) and 29 patients showed ganglionar metastasis (90.6\%). In the group 1 , nineteen patients received adjuvant therapy with tamoxifen, 20 were treated with chemotherapy and tamoxifen, 5 with chemotherapy only and 1 of them received radiotherapy. In the group 2 , three patients received adjuvance with tamoxifen, 19 tamoxifen and chemotherapy, 4 received chemotherapy only and 5 adjuvant endocrine therapy without tamoxifen. 27 patients received a second-line of chemotherapy and 14 died between 2 and 32 months after the diagnosis of metastasis.

\section{Immunoblotting}

For Western blot analysis, each sample was homogenised in 0.5 M Tris-HCl buffer ( $\mathrm{pH} 7.4$ ) containing $1 \mathrm{mM}$ EDTA, $12 \mathrm{mM}$ 2-mercaptoethanol, $1 \mathrm{mM}$ benzamidine, and 1 
$\mathrm{mM}$ phenylmethylsulphonyl fluoride (PMSF), with the addition of a cocktail of protease inhibitors $(10 \mathrm{mM}$ iodoacetamide, $0.01 \mathrm{mg} / \mathrm{ml}$ of soybean trypsin inhibitor and $1 \mu \mathrm{l} / \mathrm{ml}$ of leupeptin) and phosphatase inhibitors (10 $\mathrm{mM}$ sodium fluoride and $1 \mathrm{mM}$ sodium orthovanadate) in the presence of $0.5 \%$ Triton X-100. Homogenates were centrifuged for $10 \mathrm{~min}$ at $15000 \times \mathrm{g}$. After boiling for 2 min at $98^{\circ} \mathrm{C}$, aliquots of $70 \mu \mathrm{g}$ of protein were separated in SDS-polyacrylamide ( $9 \% \mathrm{w} / \mathrm{v}$ ) slab minigels. Separated proteins were transferred for $4 \mathrm{~h}$ at $0.25 \mathrm{~A}$ to nitrocellulose membranes $(0.2 \mu \mathrm{m})$ and, thereafter, the nitrocellulose sheets were blocked for $1 \mathrm{~h}$ with $5 \%$ blotto in $0.05 \mathrm{M}$ Tris$\mathrm{HCl}$ and incubated overnight with the primary antibodies diluted 1:200 (RXR- $\alpha$ and $-\gamma$ ), and 1:100 (RXR- $\beta$, hPXR1, and hPXR1.2) in blocking solution $1: 9$ overnight at $37^{\circ} \mathrm{C}$.

For RXRs, the blots were incubated with peroxidase-linked secondary antibody (Chemicon) diluted 1:4000 for 1 hour at room temperature. For hPXR1 and hPXR1.2, swine anti-goat and goat anti-rabbit biotinylated immunoglobulins (Dako, Barcelona, Spain) were used at 1:1000 dilution in blocking solution 1:9 for $1 \mathrm{~h}$ at room temperature, and then the membranes were incubated with streptavidin-peroxidase complex (Zymed, CA, USA). Antibody/protein complexes were detected using ECL (Amersham, Buckinghamshire, UK).

Extracts from breast cancer cell lines (MCF-7 and MDAMB-231) were used as positive controls for hPXR1.2 and hPXR1 antibodies. Blots were stripped and re-probed with an anti-human $\beta$-actin monoclonal antibody (Sigma) to control for equal sample loading.

\section{Immunohistochemistry}

Sections of $5-\mu \mathrm{m}$-thickness were deparaffined, hydrated and incubated for $20 \mathrm{~min}$ in $0.3 \% \mathrm{H}_{2} \mathrm{O}_{2}$ to inhibit endogenous peroxidase activity, and for antigen retrieval, incubated with $0.1 \mathrm{M}$ citrate buffer ( $\mathrm{pH} 6$ ) for $10 \mathrm{~min}$. at $96^{\circ} \mathrm{C}$. After rinsing in TBS, the slides were incubated with $3 \%$ normal donkey serum (NDS) in TBS for $30 \mathrm{~min}$ to prevent non-specific binding of the first antibody. Afterwards, they were incubated overnight at $37^{\circ} \mathrm{C}$ with the RXR- $\alpha$ and RXR- $\gamma$ rabbit polyclonal antibodies and RXR- $\beta$ mouse monoclonal primary antibody (Santa Cruz Biotechnologies, CA, USA), diluted 1:20 in blocking solution 1:9; rabbit polyclonal hPXR (that reacts with the isoforms 1 and 2 of PXR) (Active Motif, Rixensart, Belgium) at 1:300 dilution, and goat polyclonal hPXR1 (isoform 1) diluted 1/20 (Santa Cruz). The sections were washed in TBS and incubated with swine anti-goat (for hPXR1), swine anti-rabbit (for hPXR1.2, RXR- $\alpha$ and RXR- $\gamma$ ), or rabbit anti-mouse (for RXR- $\beta$ ) biotinylated immunoglobulins (Dako, Barcelona, Spain) all of them at 1:400 dilution during $1 \mathrm{~h}$. Thereafter, they were incubated with avidin-biotin-peroxidase complex (Dako) and developed with 3, 3'-diami- nobenzidine (DAB) using the glucose oxidase-DAB-nickel intensification method. The sections were dehydrated, cleared in xylene, and mounted in DePex (Probus, Badalona, Spain).

To assess the specificity of immunoreactions, negative and positive controls were used. As negative controls, sections of breast samples processed identically were incubated using the antibody preabsorbed with corresponding blocking peptide, or omitting the primary antibody. As positive controls, sections of human liver, intestine for hPXR1.2 and hPXR1, and human skin for the three isoforms of RXR were processed with the same antibody.

The staining intensity of hPXR and RXRs receptors was classified in two categories: 0, negative or staining was observed in less than $10 \%$ of the cells; 1 , staining was detected in more than $10 \%$ of the cells. In contrast to nuclear staining, the staining pattern of the extranuclear expression for these proteins was observed in two types: diffuse staining and spotted staining in the cytoplasm according to the following criteria: score 0 , no staining at all; 1 , a weak staining; 2 , a moderate to strong staining was observed in more than $10 \%$ of the tumour cells. The assessment of the grade of staining was performed in a blinded way always by the same experienced investigators (IC, MIA) in high-power fields $(\times 400)$ using standard light microscopy.

\section{Statistical analysis}

To evaluate the differences between hPXR and RXRs expression for each of the different pathology types (BBDs, CIS, IDC and ILC), we performed overall comparisons using non-parametric ANOVA (Kruskal-Wallis test). In infiltrative carcinomas, univariate analysis comparing categorical variables (hPXR, RXR, ER and PR expression and clinicopathological data) was performed using chisquare tests. Given the low expected frequencies found in the majority of the crosstabulations, we used Fisher exact test to compute $p$-values. We test for the presence of a linear trend when there were more than two categories of staining using Mantel-Haenszel chi-square statistic. Time to post-operative recurrence was analyzed using KaplanMeier estimations of disease free survival curves. Survival curves were compared with log-rank test. We adopt a 5\% significance level. All analyses were performed with SPSS version 13.0 for Windows.

\section{Results}

\section{Western blot analysis}

Results from Western blot analysis are shown in Figure 1. In breast cancer cell lines, hPXR1.2 antibody showed two distinctive immunoreactive bands at 40 and $70 \mathrm{kDa}$; in MDA-MB-231 cells an additional band at $90 \mathrm{kDa}$ and other fainter band at $\sim 28 \mathrm{kDa}$ were observed. In CIS, three 

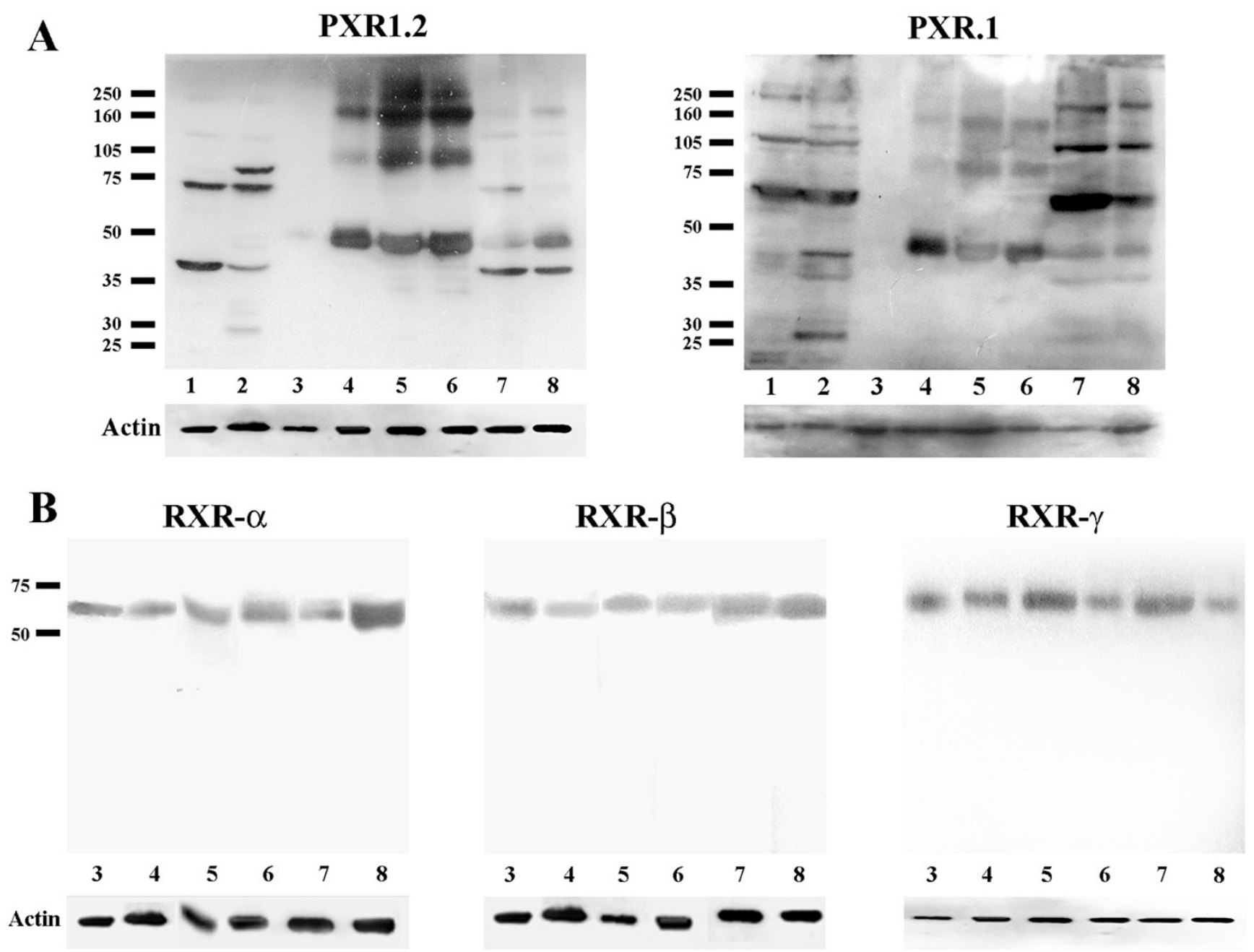

\section{Figure I}

A. Western blot analysis for hPXRI.2 and hPXRI antibodies. With hPXRI.2 antibody, in MCF-7 cells were detected mainly two bands at 40 and $70 \mathrm{kDa}$; however, in MDA-MB-23I can be also observed additional bands at 28 and $90 \mathrm{kDa}$. In this last cell line, with hPXRI antibody multiple bands at 28, 37, 40, 70, 120 and $250 \mathrm{kDa}$; however, in MCF-7 were only detected bands at 70, 120 and $250 \mathrm{kDa}$. In benign breast diseases no bands were observed either with hPXRI.2 or with hPXRI antibody. In carcinomas in situ, bands at 50, 100 and $160 \mathrm{kDa}$ were observed with both antibodies. In infiltrative carcinomas, those samples incubated with hPXRI.2 presented multiple bands at approximately 40, 50 and $70 \mathrm{kDa}$.; while in samples incubated with hPXRI antibody, five immunoreactive bands at 40, 50, 70, 120 and $250 \mathrm{kDa}$ were observed. B. Western blot analysis for RXRs antibodies. For $R X R-\alpha, R X R-\beta$ and $R X R-\gamma$, only a single band at $60 \mathrm{kDa}$ of molecular weight was found in all pathologies studied. For all figures: Lane I: MCF-7 cells. Lane 2: MDA-MB-23I cells. Lane 3: benign breast diseases. Lane 4: Ductal carcinoma in situ. Lanes 5 and 6: Lobular carcinoma in situ. Lane 7: Infiltrative ductal carcinoma. Lane 8: Infiltrative lobular carcinoma. Each blot is representative of its respective group. After stripping, immunoreactivity with an anti-actin antibody was used as loading control (actin, bottom panels).

bands were detected at 50, 100 and $160 \mathrm{kDa}$. Infiltrative carcinomas showed a strong band at $40 \mathrm{kDa}$, and additional protein bands at 50 and $70 \mathrm{kDa}$. When the same samples were incubated with the antibody that exclusively recognizes the hPXR1 isoform, multiple bands were observed in MDA-MB-231 cells, at approximately 28, 40, 70, 120 and $250 \mathrm{kDa}$ (Fig. 1B). In MCF-7 cells only the 70,
120 and $250 \mathrm{KDa}$ were detected. Carcinomas in situ samples showed the same three bands detected with hPXR1.2 antibody at 50, 100 and $160 \mathrm{kDa}$. In infiltrative carcinomas, hPXR1 antibody detected immunoreactive protein bands at approximately 50, 70, 120 and $250 \mathrm{kDa}$. No immunoreaction to hPXR1.2 or to hPXR1 was detected in samples from benign breast diseases. 


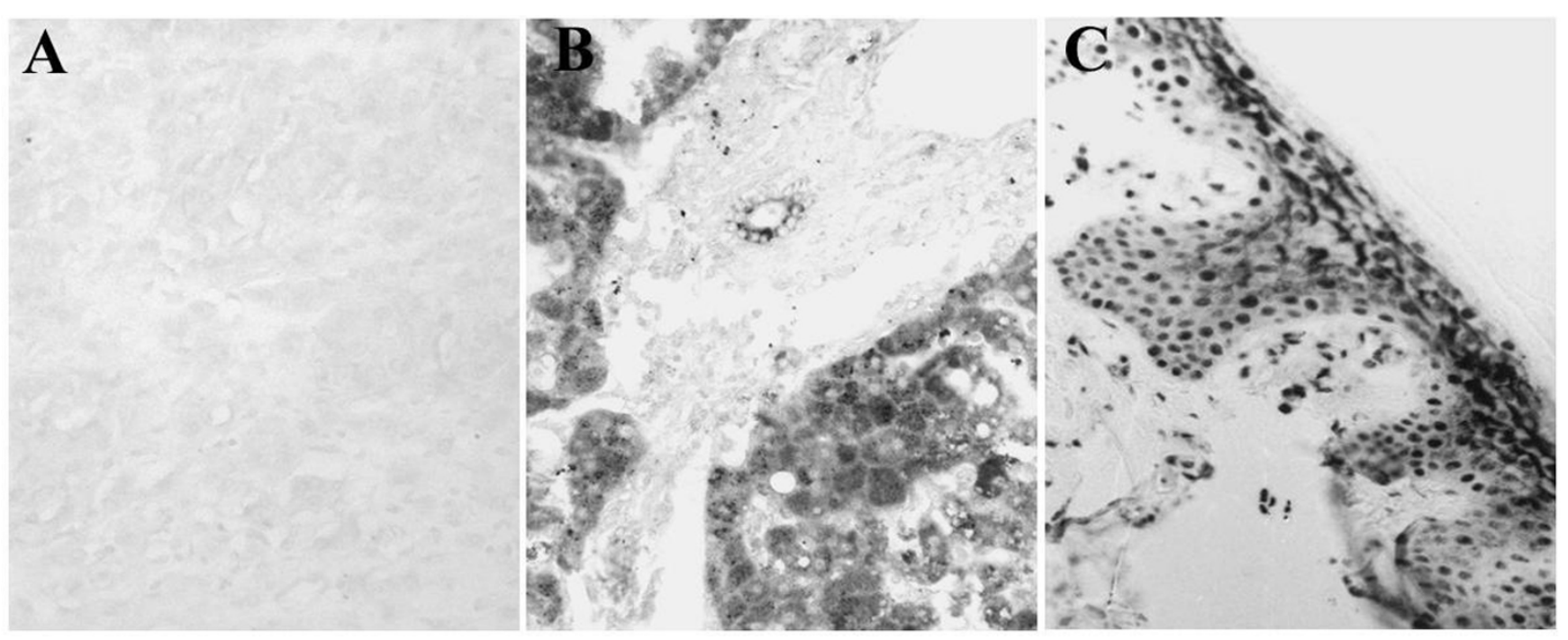

\section{Figure 2}

A. Negative control section of infiltrative ductal carcinoma was obtained when it was incubated with antibody pre-absorbed with blocking peptide $(\times 250)$.B. Control section from human liver with an intense reaction to hPXRI.2 antibody in the cytoplasm of hepatocytes $(\times 250)$. C. Control section of human skin. The nuclei of keratinocytes were intensely labelled for $R X R a$ $(\times 250)$.

In all the samples studied, RXR- $\alpha$, RXR- $\beta$ and RXR- $\gamma$ antibodies showed a single band with a molecular weight of $60 \mathrm{kDa}$.

\section{Immunohistochemical study of control sections}

The immunohistochemical study showed no reaction in the negative controls obtained when they were incubated with antibody pre-absorbed with blocking peptide (Fig. 2A). Positive controls for hPXRs antibodies showed an intense immunoreaction in the cytoplasm of hepatocytes (Figure 2B). Immunostaining of human skin sections were always positive to RXRs antibodies (Figure 2C).

\section{Immunohistochemical detection of hPXR}

hPXR1.2 was detected in the cytoplasm in the most of samples (Table 1). In normal breast ducts and acini, only some myoepithelial and endothelial cells were immunoreactive. In BBDs, a cytoplasmic immunoreaction to hPXR1.2 in the epithelial cells was also detected (Fig. 3A). Carcinomatous lesions showed some variations in hPXR1.2 expression; thus, 90\% of CIS showed cytoplasmic reaction (Fig. $3 \mathrm{~B}$ ); while in IDC, the $100 \%$ of samples presented cytoplasmic reaction, and the $45.8 \%$ of samples showed nuclear immunolabelling (Fig. 3C). Infiltrative lobular carcinomas showed higher nuclear immunoreaction (80\%) (Fig. 3D).

hPXR1 isoform showed a similar expression pattern to hPXR1.2 in benign lesions and CIS (Figs. 3E and 3F). However, infiltrative carcinomas only showed cytoplasmic immunoreactivity (Figs. 3G and 3H).

Table I: Immunohistochemical expression of Retinoid X receptors and hPXR isoforms in human breast lesions.

\begin{tabular}{|c|c|c|c|c|c|c|c|c|c|c|}
\hline & \multicolumn{2}{|c|}{ BBDs $(n=12)$} & \multicolumn{2}{|c|}{$\operatorname{CIS}(n=10)$} & \multicolumn{2}{|c|}{ IDC $(n=54)$} & \multicolumn{2}{|c|}{ ILC $(n=23)$} & \multicolumn{2}{|c|}{ p-value } \\
\hline & $\mathbf{N}$ & C & $\mathbf{N}$ & C & $\mathbf{N}$ & C & $\mathbf{N}$ & C & $\mathbf{N}$ & C \\
\hline hPXRI.2 & 0 & $6(50 \%)$ & 0 & $9(90 \%)$ & 15 (27.8\%) & $54(100 \%)$ & 7 (30.4\%) & $23(100 \%)$ & 0.048 & $<0.001$ \\
\hline hPXRI & 0 & $4(33.4 \%)$ & 0 & $8(80 \%)$ & 0 & $54(100 \%)$ & 0 & $23(100 \%)$ & 1.000 & $<0.001$ \\
\hline $\mathbf{R X R}-\alpha$ & 0 & I (8.4\%) & 0 & $2(20 \%)$ & $23(42.6 \%)$ & 25 (46.3\%) & II (47.8\%) & $8(34.8 \%)$ & 0.002 & 0.037 \\
\hline $\mathbf{R X R}-\beta$ & 0 & 0 & 0 & $3(30 \%)$ & $8(14.8 \%)$ & 30 (55.6\%) & $2(8.7 \%)$ & $12(52.1 \%)$ & 0.301 & 0.003 \\
\hline $\mathbf{R X R}-\gamma$ & 0 & $2(16.7 \%)$ & 0 & $4(40 \%)$ & $8(14.8 \%)$ & 35 (64.8\%) & 5 (21.7\%) & $10(43.5 \%)$ & 0.161 & 0.002 \\
\hline
\end{tabular}

Numbers represent the frequencies and percentages of cases with positive reaction. BBDs: benign breast diseases. CIS: carcinoma in situ. IDC: infiltrative ductal carcinoma. ILC: infiltrative lobular carcinoma. $\mathbf{n}$ : number of cases. $\mathbf{N}$ : nucleus. C: cytoplasm. ' $p$-values obtained by one-way Kruskal-Wallis test to compare overall between pathological groups differences in the degree of staining. 

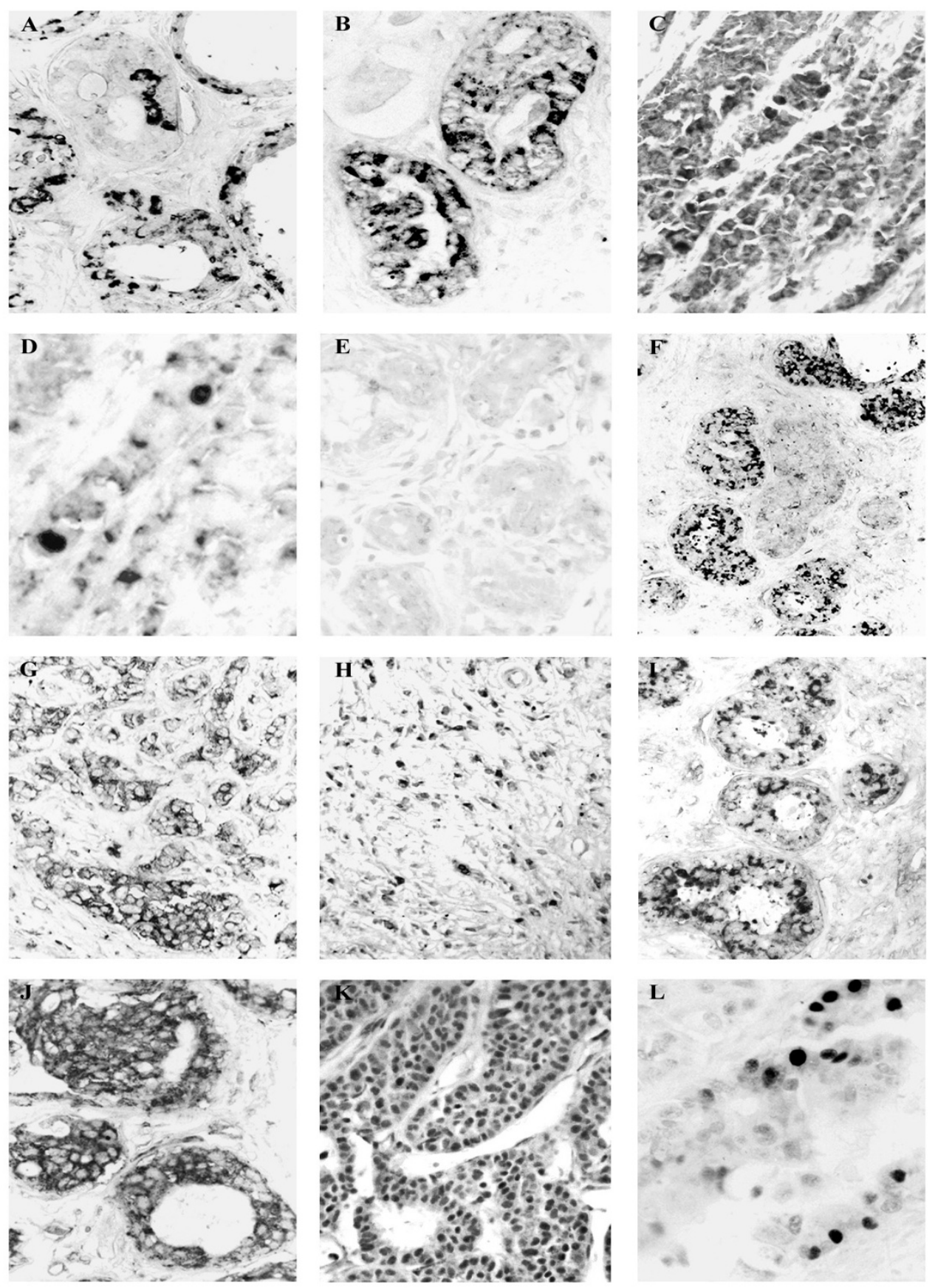

Figure 3

Immunohistochemical detection of $h P X R$ and $R X R$ receptors. Immunoreaction to $h P X R I .2$ (A, B, C and D). In ductal hyperplasia $(\mathbf{A})(\times 250)$ and ductal carcinoma in situ $(\mathbf{B})(\times 250)$, the reaction was observed in the cytoplasm. In infiltrative ductal carcinoma (C) $(\times 250)$ and infiltrative lobular carcinoma $(\mathbf{D})(\times 500)$, the hPXRI.2 immunoexpression was also observed in the nucleus of neoplastic cells. Immunoreaction to $\mathbf{h P X R I}(\mathbf{E}, \mathbf{F}, \mathbf{G}$ and $\mathbf{H})$ ). Lobular hyperplasia $(\mathbf{E})(\times 200)$ showing no immunoreaction to $\mathrm{hPXRI}$ antibody. Micrograph of lobular carcinoma in situ (F) $(\times 200)$, infiltrative ductal carcinoma $(\mathbf{G})$ $(\times 200)$ and infiltrative lobular carcinoma $(\mathbf{H})(\times 200)$ with cytoplasmic immunolocation of $h P X R I$ isoform. Immunoreaction to RXR- $\alpha$ (I, J, K and L). Cytoplasmic immunolabelling of RXR- $\alpha$ in samples of ductal hyperplasia (I) $(\times 200)$ and ductal carcinoma in situ $(\mathbf{J})(\times 300)$. Neoplastic cells from infiltrative ductal carcinoma $(\mathbf{K})(\times 300)$ and infiltrative lobular carcinoma $(\mathbf{L})$ $(\times 500)$ presenting a nuclear immunoexpression to $R X R-\alpha$. 
The most important difference between the patient groups was that patients who evolved to recurrent disease showed cells with nuclear staining to PXR1.2 antibody, but these nuclei were consistently immunonegative to PXR.1.

\section{Immunohistochemical expression of retinoid receptors}

Both benign samples and CIS showed only cytoplasmic immunoreaction to RXR- $\alpha$ (Figs. 3I and 3J). However, in both ductal and lobular infiltrative carcinomas this receptor was also observed in the nucleus of neoplastic cells (Figs. 3K and 3L).

The percentage of positive cases for RXR- $\beta$ was similar to that of RXR- $\alpha$ in BBDs and CIS, and lower in infiltrative carcinomas; in IDC, only one case of nuclear immunoreaction was observed.

The immunoexpression observed for RXR- $\gamma$ was similar to that of RXR- $\alpha$, although the percentage of samples with cytoplasmic immunoreaction was always higher and lower that of nuclear expression.

\section{Statistical analysis}

The Fisher's exact tests realized between the RXR and hPXR isoforms (Table 2) showed a positive association between the expression of hPXR isoforms and nuclear and cytoplasmic RXR- $\alpha$ expression. Also, a positive association between the expression of both hPXR isoforms and cytoplasmic expression of both RXR- $\beta$ and RXR- $\gamma$ was encountered.

The associations between the hPXR isoforms expression and the clinicopathological data of patients are reflected in Table 3. Patient's age was homogeneous and independent on hPXR results. hPXR expression was not associated with tumour type. The nuclear hPXR1.2 expression was significantly more frequent in patients with positive nodal status. hPXR expression was inversely correlated with ER expression while that of PR was correlated with the nuclear and cytoplasmic expression of hPXR1.2 and the hPXR1 cytoplasmic expression. hPXR expression was inversely correlated with recurrence and disease-free interval (Fig. 4).

The associations between the RXRs expression and the clinicopathological data are reflected in Tables 4 and 5 .

Table 2: Fisher's exact test between the expression of the different isoforms of hPXR and that the retinoid receptors in infiltrative carcinomas.

\begin{tabular}{|c|c|c|c|c|c|c|c|c|c|c|c|}
\hline & & \multirow[b]{2}{*}{ Total } & \multicolumn{3}{|c|}{ hPXRI.2 C } & \multicolumn{3}{|c|}{ hPXRI.2 N } & \multicolumn{3}{|c|}{ hPXRI C } \\
\hline & & & Weak & High & p-value & Negative & Positive & p-value & Weak & High & p-value \\
\hline \multirow[t]{4}{*}{$\mathbf{R X R}-\alpha \mathbf{C}$} & Negative & 45 & 17 & 28 & 0.035 & 24 & 21 & $<0.001$ & 19 & 26 & 0.007 \\
\hline & Weak & 6 & 5 & I & & 6 & 0 & & 5 & I & \\
\hline & High & 26 & 16 & 10 & & 25 & 1 & & 20 & 6 & \\
\hline & Total & 77 & 38 & 39 & & 55 & 22 & & 44 & 33 & \\
\hline \multirow[t]{3}{*}{$\mathbf{R X R}-\alpha \mathbf{N}$} & Negative & 43 & 30 & 13 & $<0.001$ & 42 & 1 & $<0.001$ & 34 & 9 & $<0.001$ \\
\hline & Positive & 34 & 8 & 26 & & 13 & 21 & & 10 & 24 & \\
\hline & Total & 77 & 38 & 39 & & 55 & 22 & & 44 & 33 & \\
\hline \multirow[t]{4}{*}{$\mathbf{R X R}-\beta \mathbf{C}$} & Negative & 35 & 18 & 17 & 0.021 & 22 & 13 & 0.045 & 18 & 17 & 0.329 \\
\hline & Weak & 18 & 13 & 5 & & 17 & 1 & & 13 & 5 & \\
\hline & High & 24 & 7 & 17 & & 16 & 8 & & 13 & 11 & \\
\hline & Total & 77 & 38 & 39 & & 55 & 22 & & 44 & 33 & \\
\hline \multirow[t]{3}{*}{$\mathbf{R X R}-\beta \mathbf{N}$} & Negative & 67 & 32 & 35 & 0.470 & 48 & 19 & 0.915 & 38 & 29 & 0.845 \\
\hline & Positive & 10 & 6 & 4 & & 7 & 3 & & 6 & 4 & \\
\hline & Total & 77 & 38 & 39 & & 55 & 22 & & 44 & 33 & \\
\hline \multirow[t]{4}{*}{$\mathbf{R X R}-\gamma \mathbf{C}$} & Negative & 32 & 21 & 11 & 0.001 & 28 & 4 & 0.001 & 24 & 8 & $<0.001$ \\
\hline & Weak & 12 & 9 & 3 & & 11 & 1 & & 10 & 2 & \\
\hline & High & 33 & 8 & 25 & & 16 & 17 & & 10 & 23 & \\
\hline & Total & 77 & 38 & 39 & & 55 & 22 & & 44 & 33 & \\
\hline \multirow[t]{3}{*}{$\mathbf{R X R}-\gamma \mathbf{N}$} & Negative & 64 & 34 & 30 & 0.142 & 46 & 18 & 0.847 & 37 & 27 & 0.792 \\
\hline & Positive & 13 & 4 & 9 & & 9 & 4 & & 7 & 6 & \\
\hline & Total & 77 & 38 & 39 & & 55 & 22 & & 44 & 33 & \\
\hline
\end{tabular}

C: Cytoplasmic immunoreaction. $\mathbf{N}$ : nuclear immunoreaction. 
Table 3: Fisher's exact test between hPXR expression and different clinicopathological data of the patients presenting infiltrative carcinomas.

\begin{tabular}{|c|c|c|c|c|c|c|c|c|c|c|c|}
\hline & & \multirow[b]{2}{*}{ Total } & \multicolumn{3}{|c|}{ hPXRI.2 C } & \multicolumn{3}{|c|}{ hPXRI.2 N } & \multicolumn{3}{|c|}{ hPXRI C } \\
\hline & & & Weak & High & p-value & Negative & Positive & p-value & Weak & High & p-value \\
\hline \multirow[t]{2}{*}{ Tumor Type } & Ductal & 54 & 26 & 28 & 0.613 & 39 & 15 & 0.002 & 33 & 21 & 0.374 \\
\hline & Lobular & 22 & 12 & 10 & & 16 & 6 & & 11 & 11 & \\
\hline \multirow[t]{2}{*}{ Age } & $<50$ & 19 & 13 & 6 & 0.055 & 13 & 6 & 0.738 & 12 & 7 & 0.542 \\
\hline & $>50$ & 58 & 25 & 33 & & 42 & 16 & & 32 & 26 & \\
\hline \multirow[t]{4}{*}{ Tumor size } & I & 31 & 20 & 11 & 0.083 & 27 & 4 & 0.077 & 23 & 8 & 0.088 \\
\hline & 2 & 33 & 15 & 18 & & 21 & 12 & & 16 & 17 & \\
\hline & 3 & 5 & 1 & 4 & & 3 & 2 & & 2 & 3 & \\
\hline & 4 & 8 & 2 & 6 & & 4 & 4 & & 3 & 5 & \\
\hline \multirow[t]{2}{*}{ Nodal status } & - & 35 & 20 & 15 & 0.212 & 30 & 5 & 0.011 & 21 & 14 & 0.644 \\
\hline & + & 42 & 18 & 24 & & 25 & 17 & & 23 & 19 & \\
\hline \multirow[t]{4}{*}{ ER } & 0 & 17 & 7 & 10 & 0.257 & 9 & 8 & 0.001 & 10 & 7 & 0.161 \\
\hline & I & 6 & 1 & 5 & & 1 & 5 & & I & 5 & \\
\hline & 2 & 12 & 6 & 6 & & 9 & 3 & & 6 & 6 & \\
\hline & 3 & 42 & 24 & 18 & & 36 & 6 & & 27 & 15 & \\
\hline \multirow[t]{4}{*}{ PR } & 0 & 21 & 10 & 11 & 0.031 & 14 & 7 & 0.000 & 12 & 9 & 0.004 \\
\hline & I & 7 & 0 & 7 & & 0 & 7 & & 0 & 7 & \\
\hline & 2 & 13 & 6 & 7 & & 10 & 3 & & 6 & 7 & \\
\hline & 3 & 36 & 22 & 14 & & 31 & 5 & & 26 & 10 & \\
\hline
\end{tabular}

Tumor size (TNM): T = I, 2, 3, 4. ER and PR: $\mathbf{0}=$ Negative, I = Weak immunoreaction, 2/3 = High immunoreaction. C: Cytoplasmic immunoreaction. $\mathbf{N}$ : nuclear immunoreaction.

Nodal status was correlated with cytoplasmic expression of both RXR- $\beta$ and RXR- $\gamma$. The cytoplasmic expression of RXR- $\gamma$ was inversely correlated with ER and PR expression and RXR- $\alpha$ nuclear expression was correlated with that of PR. Relapse and survival were correlated with cytoplasmic expression of RXR- $\beta$ and RXR- $\gamma$ and with nuclear expression of RXR- $\alpha$ (Fig. 5).

\section{Discussion}

hPXR has been shown to activate transcription of reporter genes through a response element conserved in the promoter of the CYP3A genes $[3,5]$, suggesting that hPXR might be a transcriptional regulator of CYP3A expression [5]. Because these CYP3A enzymes have also been found in human breast cancer tissues $[13,18]$, hPXR/CYP3A-regulated pathways might be involved in therapy response of breast cancer. Thus, the first step to evaluate the functions of hPXR/CYP3A in breast cancer it would be to determinate the expression pattern of the hPXR proteins. This study provides evidence that both hPXR isoforms are expressed in human breast cancer but not in normal glands, although a previous report showed that theirs transcripts are expressed in both normal and neoplastic human breast tissue [14]. Our findings suggest that translation of mRNA might only occurs in breast cancer; simi- lar results have been reported by Miki et al. [15] who detected the presence of hPXR mRNA and protein in breast carcinomatous tissues but not in nonneoplastic and stromal cells.

The presence of different hPXR isoforms in breast lesions has been observed by Western blot analysis. By using MCF-7 and MDA-MB-237 cells to control antibodies immunoreactivity, we observed that the latter presented multiple distinctive bands and that the bands at 28 and 90 $\mathrm{kDa}$ probably belong to the hPXR.2 isoform. Samples from CIS showed identical immunoreactive bands with the two antibodies we used. Furthermore, infiltrative carcinomas showed a similar pattern to that encountered in MDA-MB-231 cells. These results agree with previous findings that suggest that hPXR is expressed as multiple forms, due to alternative as well as defective gene splicing [19]; therefore, in the same tissue, interindividual differences in hPXR transcript and protein profiles may exist. In addition, a different expression of three PXR isoforms have been detected in human liver and hepatoma cells, stomach, adrenal gland, bone marrow and brain $[2,20]$.

A previous report showed that mRNA of hPXR variants 1 and 2 is expressed in several cell lines, such as MCF-7 or 


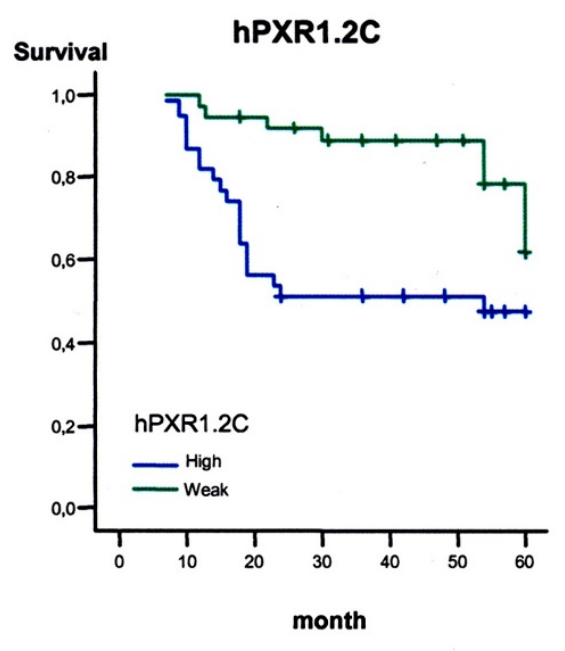

Log-rank $p=0.0086$

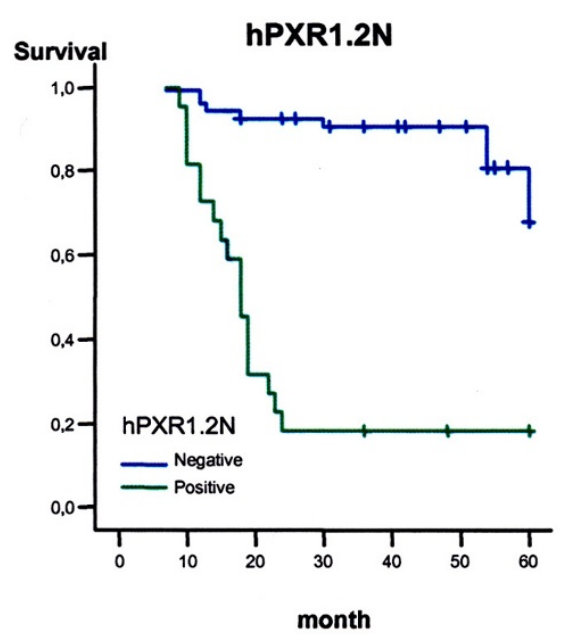

Log-rank $p=0.0000$

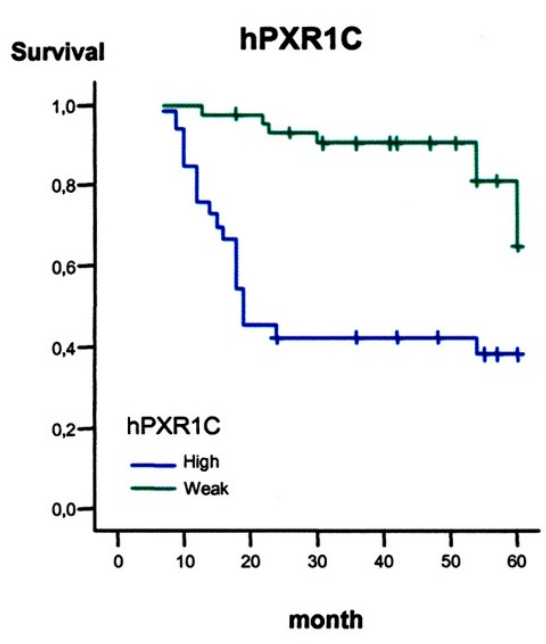

Log-rank $p=0.0001$

\section{Figure 4}

Kaplan-Meier disease-free survival curves for 77 patients with infiltrative carcinomas according to the $\mathbf{h P X R}$ expression. Marks represent censored data. Statistical significance was determined by the Log Rank test.

Table 4: Fisher's exact test between RXRs cytoplasmic expression and different clinicopathological data of the patients presenting infiltrative carcinomas.

\begin{tabular}{|c|c|c|c|c|c|c|c|c|c|c|c|c|c|}
\hline & & \multicolumn{4}{|c|}{$\mathbf{R X R}-\alpha \mathbf{C}$} & \multicolumn{4}{|c|}{$\mathbf{R X R}-\beta \mathbf{C}$} & \multicolumn{4}{|c|}{$\mathbf{R X R}-\gamma \mathbf{C}$} \\
\hline & & Negative & Weak & High & p-value & Negative & Weak & High & p-value & Negative & Weak & High & p-value \\
\hline \multirow{2}{*}{$\begin{array}{l}\text { Tumor } \\
\text { Type }\end{array}$} & Ductal & 30 & 3 & 21 & 0.264 & 24 & 12 & 18 & 0.838 & 19 & 10 & 25 & 0.151 \\
\hline & Lobular & 14 & 3 & 5 & & 10 & 6 & 6 & & 13 & 2 & 7 & \\
\hline \multirow[t]{2}{*}{ Age } & $<50$ & 12 & 3 & 4 & 0.185 & 10 & 4 & 5 & 0.765 & 5 & 3 & 11 & 0.254 \\
\hline & $>50$ & 33 & 3 & 22 & & 25 & 14 & 19 & & 27 & 9 & 22 & \\
\hline \multirow[t]{4}{*}{ Tumor size } & 1 & 15 & 4 & 12 & 0.697 & 12 & 11 & 8 & 0.292 & 15 & 7 & 9 & 0.392 \\
\hline & 2 & 22 & 2 & 9 & & 17 & 4 & 12 & & 12 & 5 & 16 & \\
\hline & 3 & 3 & 0 & 2 & & I & 2 & 2 & & 2 & 0 & 3 & \\
\hline & 4 & 5 & 0 & 3 & & 5 & 1 & 2 & & 3 & 0 & 5 & \\
\hline \multirow{2}{*}{$\begin{array}{l}\text { Nodal } \\
\text { status }\end{array}$} & - & 22 & 3 & 10 & 0.678 & 17 & 12 & 6 & 0.024 & 18 & 9 & 8 & 0.003 \\
\hline & + & 23 & 3 & 16 & & 18 & 6 & 18 & & 14 & 3 & 25 & \\
\hline \multirow[t]{4}{*}{ ER } & 0 & 10 & 0 & 7 & 0.274 & 6 & 2 & 9 & 0.060 & 2 & 3 & 12 & 0.000 \\
\hline & I & 6 & 0 & 0 & & 3 & 0 & 3 & & 1 & 0 & 5 & \\
\hline & 2 & 6 & 2 & 4 & & 4 & 6 & 2 & & 2 & 4 & 6 & \\
\hline & 3 & 23 & 4 & 15 & & 22 & 10 & 10 & & 27 & 5 & 10 & \\
\hline \multirow[t]{4}{*}{ PR } & 0 & 13 & 1 & 7 & 0.296 & II & 5 & 5 & 0.480 & 9 & 2 & 10 & 0.009 \\
\hline & I & 7 & 0 & 0 & & 3 & 0 & 4 & & 0 & 0 & 7 & \\
\hline & 2 & 8 & I & 4 & & 5 & 5 & 3 & & 4 & 5 & 4 & \\
\hline & 3 & 17 & 4 & 15 & & 16 & 8 & 12 & & 19 & 5 & 12 & \\
\hline
\end{tabular}

Tumor size (TNM): T = I, 2, 3, 4. ER and PR: $\mathbf{0}=$ Negative, I = Weak immunoreaction, 2/3 = High immunoreaction. C: Cytoplasmic immunoreaction. 
Table 5: Fisher's exact test between RXRs nuclear expression and different clinicopathological data of the patients presenting infiltrative carcinomas.

\begin{tabular}{|c|c|c|c|c|c|c|c|c|c|c|}
\hline & & \multicolumn{3}{|c|}{$\mathbf{R X R}-\alpha \mathbf{N}$} & \multicolumn{3}{|c|}{$\mathbf{R} \times \mathbf{R}-\beta \mathbf{N}$} & \multicolumn{3}{|c|}{$\mathbf{R X R}-\gamma \mathbf{N}$} \\
\hline & & Negative & Positive & p-value & Negative & Positive & p-value & Negative & Positive & p-value \\
\hline \multirow[t]{2}{*}{ Tumor Type } & Ductal & 31 & 23 & 0.819 & 46 & 8 & 0.503 & 46 & 8 & 0.406 \\
\hline & Lobular & 12 & 10 & & 20 & 2 & & 17 & 5 & \\
\hline \multirow[t]{2}{*}{ Age } & $<50$ & 9 & 10 & 0.391 & 17 & 2 & 0.713 & 17 & 2 & 0.394 \\
\hline & $>50$ & 34 & 24 & & 50 & 8 & & 47 & II & \\
\hline \multirow[t]{4}{*}{ Tumor size } & I & 21 & 10 & 0.304 & 27 & 4 & 0.829 & 26 & 5 & 0.123 \\
\hline & 2 & 17 & 16 & & 28 & 5 & & 30 & 3 & \\
\hline & 3 & 2 & 3 & & 5 & 0 & & 3 & 2 & \\
\hline & 4 & 3 & 5 & & 7 & 1 & & 5 & 3 & \\
\hline \multirow{2}{*}{ Nodal status } & - & 19 & 16 & 0.802 & 28 & 7 & 0.095 & 28 & 7 & 0.505 \\
\hline & + & 24 & 18 & & 39 & 3 & & 36 & 6 & \\
\hline \multirow[t]{4}{*}{ ER } & 0 & 8 & 9 & 0.093 & 15 & 2 & 0.254 & 16 & I & 0.116 \\
\hline & I & 1 & 5 & & 6 & 0 & & 6 & 0 & \\
\hline & 2 & 6 & 6 & & 12 & 0 & & 11 & 1 & \\
\hline & 3 & 28 & 14 & & 34 & 8 & & 31 & 11 & \\
\hline \multirow[t]{4}{*}{ PR } & 0 & 13 & 8 & 0.010 & 18 & 3 & 0.608 & 17 & 4 & $0.64 I$ \\
\hline & I & 0 & 7 & & 7 & 0 & & 7 & 0 & \\
\hline & 2 & 6 & 7 & & 12 & 1 & & 11 & 2 & \\
\hline & 3 & 24 & 12 & & 30 & 6 & & 29 & 7 & \\
\hline
\end{tabular}

Tumor size (TNM): T = I, 2, 3, 4. ER and PR: $\mathbf{0}=$ Negative, I = Weak immunoreaction, 2/3 = High immunoreaction. $\mathbf{N}$ : nuclear immunoreaction.

MDA-MB-231 [14], and this expression is inversely related to the ER status. The ER status is used as a therapeutic indicator and is also a prognostic marker in human breast cancer [21]. We have observed that the neoplastic cells that express nuclear hPXR1.2 and no ER immunoreactivity were strongly correlated; this inverse correlation between both receptors suggests that pathways by hPXRmediated might be functional in breast tumours with potential poor response to the endocrine adjuvance. This correlation between ER and hPXR was also found by Masuyama et al. [23] in human endometrium; these authors only detected hPXR expression in endometrial cancer tissues but not in normal endometrium and, similarly they encountered a significant inverse correlation between the expression of PXR and ER. Altogether, these results suggest that hPXR might play some role in the metabolism of steroid hormones in tumoral cells, and that may be involved in the growth and development of cancer tissue that express low ER-alpha.

We have also analysed ER and hPXR cytoplasmic expression observing the same inverse correlation between both receptors as that encountered for the nuclear immunolocation. This is in agreement to the observation by Dotzlaw et al. [14] who reported that MCF-7 cells (ER+/PR+), with a low metastatic potential, express hPXR1 mRNA but not hPXR.2 mRNA. However, MDA-MB-231 cells (ER-/PR-) with a high metastatic potential, showed the highest levels of both hPXR1 and 2 mRNA variants.

In breast cancer, the hPXR isoform 2 seems to be a functional protein since it was detected in the cell nuclei. It has been reported, in mouse liver, that PXR is retained in the cytoplasm in a complex formed by hsp90 and the cochaperone CCRP, and in presence of ligand, PXR is accumulated in the nucleus [24]. We have observed an increase of the hPXR expression in both nucleus and cytoplasm related to breast cancer progression; the biological significance of this rise correlated to neoplastic transformation is unknown; clearly, more studies are needed to elucidate this accumulation. Although the percentage of samples with nuclear immunostaining was lower than the cytoplasmic staining, the specimens with nuclear reaction corresponded to all those cases that presented resistance to conventional treatments and that metastasized later. Therefore, an important correlation between cancer recurrence and nuclear immunostaining of hPXR1.2 was observed. 


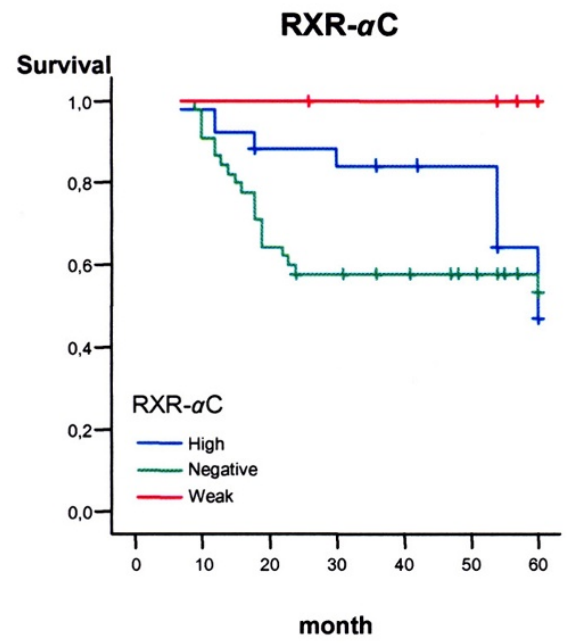

Log-rank (overall) $p=0.128$
RXR- $\beta$ C

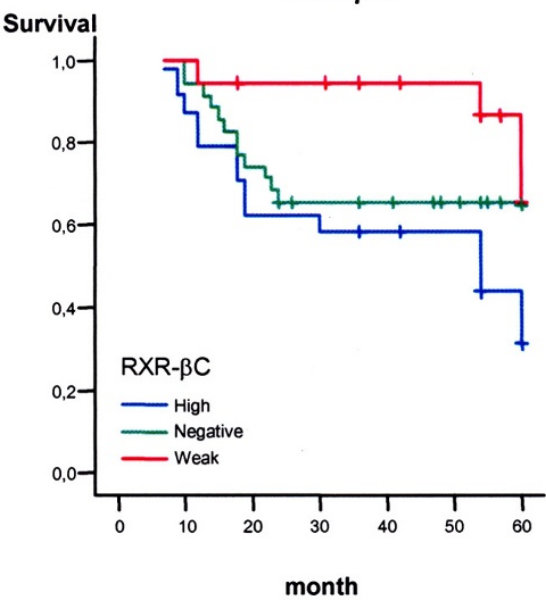

Log-rank (overall) $p=0.037$

High vs weak $p=0.012$

High vs negative $p=0.321$

Negative vs weak $p=0.077$

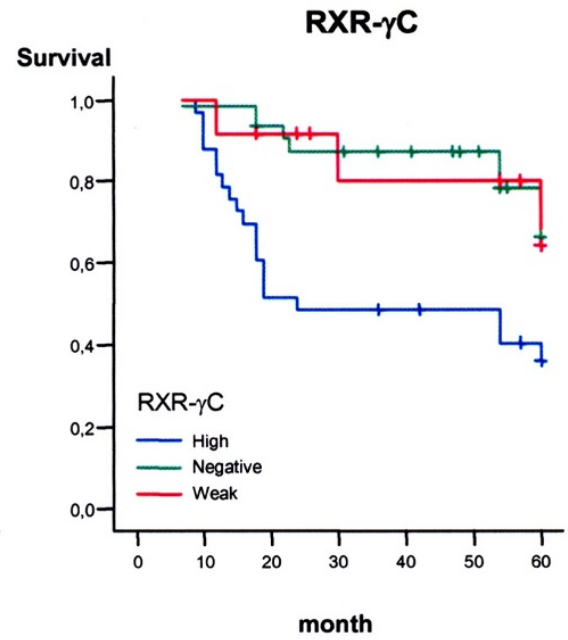

Log-rank (overall) $p=0.0029$

High vs negative $p=0.002$

High vs weak $p=0.048$

Negative vs weak $p=0.952$
RXR- $a$ N

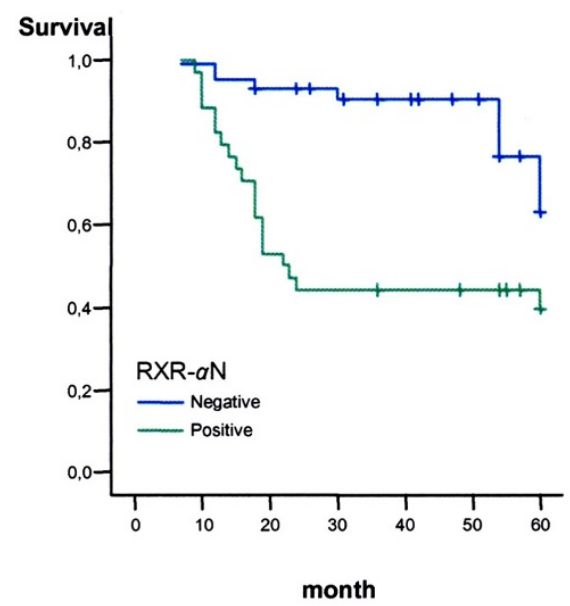

Log-rank $p=0.0014$
RXR- $\beta N$

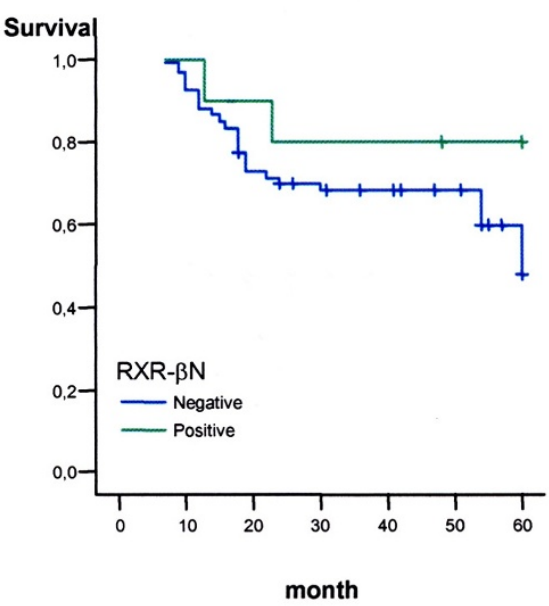

Log-rank $p=0.1292$
RXR- $\gamma$ N

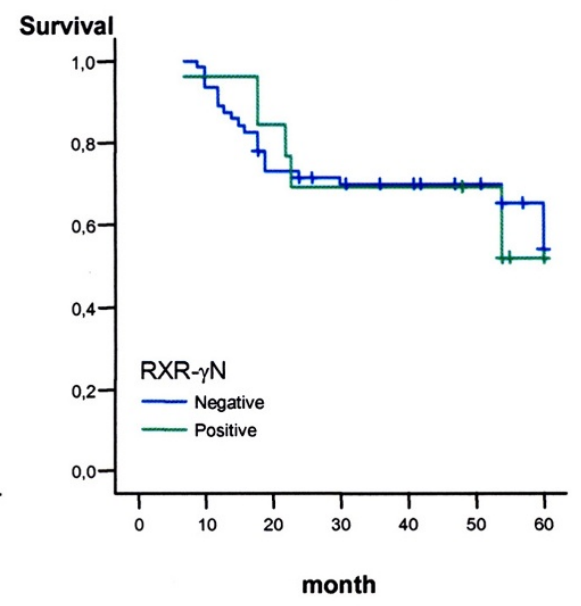

Log-rank $p=0.7911$

\section{Figure 5}

Kaplan-Meier disease-free survival curves for 77 patients with infiltrative carcinomas according to the RXR expression. Marks represent censored data. Statistical significance was determined by the Log Rank test.

RXRs are a member of the larger steroid/thyroid receptor superfamily where all members are ligand-activated transcription factors, among them RXR is unique to this group for its ability to interact with other receptors and form heterodimers complexes [25,26]. For Lawrence et al. [27], the overexpression of RXRs isoforms in ductal carcinoma in situ, especially RXR- $\alpha$, indicate an association with an increased risk for the development of invasive breast can- cer. Ariga et al. [28] detected a widely distributed expression of the three RXR isoforms in ductal carcinomas in situ; however, other authors detected RXR- $\gamma$ expression neither in breast cancer cell lines [28] nor in invasive ductal breast carcinoma [29]. None of these authors have reported cytoplasmic expression for these receptors that we have detected, the differences in immunolocation might be related to either the absence of ligand or the anti- 
body used. Moreover, it has been shown that some nuclear receptors (steroids receptors) are found as an inactive cytoplasmic form in a complex with heat shock proteins [30]. It is also possible that inactive retinoic acid nuclear receptors were forming a complex with heat shock proteins in the cytoplasm. With breast cancer progression, we have detected an increase in the percentage of samples positives for RXRs isoform; since RXR are needed partners of different nuclear receptors and there is an alternative pathway of activation for RXR as a homodimer by binding to a unique response element [31], this increase could be related to the several modifications that occur in the malignant progression.

The function of each RXR subtype in the mammary gland has yet to be defined although some studies have demonstrated an interaction between estrogen action and RXR specifically with RXR- $\alpha[29,32]$. The correlation between the expression of RXR- $\alpha$ and hPXR observed in this study supports the idea of dimerization of both receptors. Previous reports showed that different xeno-sensor target genes have different sensitivity to different xenobiotics and that RXR- $\alpha$ has an effect in gene regulation whereas RXR- $\beta$ and RXR- $\gamma$ do not [4]. Cai et al. [22] demonstrated similar data in mice that carried a RXR- $\alpha$ mutation; in hepatocytes, the level of RXR- $\alpha$ controls the basal transcription of CYP450 genes.

One of the most important drugs developed for breast cancer treatment is tamoxifen, used for systemic treatment for nearly three decades $[33,34]$. Although tamoxifen has been shown to be effective in the most tumours, some of them are unresponsive, by acquiring eventually resistance to this drug or well their growth becomes stimulated by it. There are many possible mechanisms to explain this resistance including the down-regulation, mutation, or loss of estrogen receptors, impaired co-activator signalling, and altered tamoxifen pharmacology [35].

The metabolism of tamoxifen is mainly regulated by the P450 family of cytochromes, which catalyze its conversion to both active and inactive products. In human liver CYP3A4 regulates the conversion of tamoxifen into its main active metabolite, 4-OH-tamoxifen [36]. Also, hepatic CYP3A4 can be up-regulated by hPXR throughout a mechanism involving the tamoxifen/4-OH-tamoxifen [37].

In normal human breast and breast cancer several CYP450 enzymes has been described $[16,18,38]$, as well as the expression of the CYP3A mRNA splicing forms [18]. Also, these studies showed a possible relationship among the different enzyme subclasses and the development, progression or response to antineoplastic agents [39]. Therefore, the machinery for possible in situ bioactivation of xenobiotics and modification of therapeutic drugs is present in human breast tissue. There are few available data about the relationship between tamoxifen and hPXR/ CYP450, Sane et al. [40] have reported that the CYP3A4 induction by tamoxifen and 4-OH-tamoxifen is primarily mediated by hPXR but the overall stoichiometry of other nuclear receptors such as GR and ER- $\alpha$ also contribute to the extent of the inductive effect. Huang et al. [18] considered that intratumoral hPXR levels might be useful as a predictor of response to adjuvant therapy in breast cancer patients. Synold et al. [41] have proposed that a classification of tumours as hPXR-positive or hPXR-negative might help predict whether the tumour is likely to develop chemotherapy-induced drug resistance. Our results agree with those observations since we observed that the higher levels of hPXR variants 1 and 2 are related to shorter disease-free intervals and either local recurrences or progressive disease.

\section{Conclusion}

In infiltrative carcinomas, the isoform responsible for hPXR activity is the isoform 2 . This isoform binds especially to RXR- $\alpha$ to form heterodimers which that activate transcriptional pathways in breast neoplastic cells. Since nuclear immunolocation occurs in samples from patients who presented recurrence, we suggest that the overexpression and the subcellular location changes of hPXR could be considered as a potential new prognostic indicator.

\section{Competing interests}

The authors declare that they have no competing interests.

\section{Authors' contributions}

IC and MIA designed the study, carried out the immunohistochemistry studies and have been involving in drafting the manuscript. MVTL and RP participated in Western blot analysis, result interpretation and discussion. JP participated in the immunohistochemistry studies. FJG and EA prepared and provided the tumour biological samples, reviewed the patients' histories and participated in the immunohistochemistry studies. JZ performed the statistical analysis and participated in discussion. MIA and BF participated in study coordination and supervision. All authors read, discussed and approved the final manuscript.

\section{Acknowledgements}

Authors are grateful to Dr. A. Ruiz from Department of Pathology, Hospital Príncipe de Asturias for his collaboration collecting and diagnosing the samples used in this study.

\section{References}

I. Staudinger JL, Goodwin B, Jones SA, Hawkins-Brown D, MacKenzie KI, LaTour A, Liu Y, Klaassen CD, Brown KK, Reinhard J, Willson TM, Koller $\mathrm{BH}$, Kliewer SA: The nuclear receptor PXR is a lithocholic acids sensor that protects against liver toxicity. Proc Natl Acad Sci USA 200I, 98:3369-3374. 
2. Gardner-Stephen D, Heydel JM, Goyal A, Lu Y, Xie W, Lindblom T, Mackenzie P, Radominska-Pandya A: Human PXR variants and their differential effects on the regulation of human UDP. glucuronosyltransferase gene expression. Drug Metabolism Disposition 2004, 32:340-347.

3. Kliewer SA, Moore JT, Wade L, Staudinger JL, Watson MA, Jones SA, McKee DD, Oliver BB, Willson TM, Zetterstrom RH, Perlmann T, Lehmann JM: An orphan nuclear receptor activated by pregnanes defines a novel steroid-signaling pathway. Cell 1998, 92:73-82.

4. Mangelsdorf DJ, Evans RM: The RXR heterodimers and orphan receptors. Cell 1995, 83:84I-850.

5. Lehmann JM, Mc Knee DD, Watson MA, Willson TM, Moore JT, Kliewer SA: The human orphan nuclear receptor PXR is activated by compounds that regulate CYP3A4 gene expression and cause drug interactions. J Clin Invest 1998, 102:1016-1023.

6. Blumberg B, Sabbagh WJr, Juguilon H, Bolado JJr, Van Meter CM, Ong ES, Evans RM: SXR, a novel steroid and xenobiotic-sensing nuclear receptor. Genes Dev 1998, I 2:3195-3205.

7. Zhang J, KuehI P, Green ED, Touchman JW, Watkins PB, Daly A, Hall SD, Maurel P, Relling M, Brimer C, Yasuda K, Wrighton SA, Hancock M, Kim RB, Strom S, Thummel K, Russell CG, Hudson JR, Schuetz EG, Boguski MS: The human pregnane $X$ receptor: genomic structure and identification and functional characterization of natural allelic variants. Pharmacogenetics 200 I, I I:555-572.

8. Gonzalez FJ, Liu SY, Yano M: Regulation of cytochrome P450 genes: molecular mechanisms. Pharmacogenetics 1993, 3:5I-57.

9. Zhang H, LeCluyse E, Liu L, Hu M, Matoney L, Zhu W, Yan B: Rat pregnane $X$ receptor: molecular cloning, tissue distribution and xenobiotic regulation. Arch Biochem Biophys 1999, 368: I4-22.

10. Savas U, Wester MR, Griffin KJ, Johnson EF: Rabbit pregnane $\mathbf{X}$ receptor is activated by rifampicin. Drug Metab Dispos 2000, 28:529-537.

II. LeCluyse EL: Pregnane $\mathbf{X}$ receptor: molecular basis for species differences in CYP3A induction by xenobiotics. Chem-Biol Inter 200I, I34:283-289.

12. El-Rayes BF, Ali S, Heilbrun LK, Lababidi S, Bouwman D, Visscher D, Philip PA: Cytochrome P450 and glutathione transferase expression in human breast cancer. Clin Cancer Res 2003, 9:1705-1709.

13. Kapucuoglu N, Coban T, Raunio H, Pelkonen O, Edwards RJ, Boobis $A R$, Iscan M: Expression of CYP3A4 in human breast tumor and non-tumor tissues. Cancer Lett 2003, 202:17-23.

14. Dotzlaw H, Leygue E, Watson, Murphy LC: The human orphan receptor PXR messenger RNA is expressed in both normal and neoplastic breast tissue. Clin Cancer Res 1999, 5:2 1 03-21 07.

15. Miki Y, Suzuki T, Kitada K, Yabuki N, Shibuya R, Moriya T, Ishida T, Ohuchi N, Blumberg B, Sasano H: Expression of the Steroid and Xenobiotic Receptor and its possible target gene, organic anion transporting polypeptide-A, in human breast carcinoma. Cancer Res 2006, 66:535-542.

16. Hellmold H, Rylander T, Magnusson M, Reihner E, Warner M, Gustafsson JA: Characterization of cytochrome P450 enzymes in human breast tissue from reduction mammaplasties. J Clin Endocrinol Metab 1998, 83:886-895.

17. Bieche I, Girault I, Urbain E, Tozlu S, Lidereau R: Relationship between intratumoral expression of genes coding for xenobiotic-metabolizing enzymes and benefit from adjuvant tamoxifen in estrogen receptor alpha-positive postmenopausal breast carcinoma. Breast Cancer Res 2004, 6:252-263.

18. Huang Z, Fasco M, Figge H, Keyomarsi K, Kaminsky L: Expression of cytochromes $\mathbf{P 4 5 0}$ in human breast tissue and tumors. Drug Metab Dispos 1996, 24(8):899-905.

19. Fukuen S, Fukuda T, Matsuda H, Sumida A, Yamamoto I, Inaba T, Azuma J: Identification of the novel splicing variants for the hPXR in human livers. Biochem Biophys Res Commun 2002, 298:433-438.

20. Lamba V, Yasuda K, Lamba JK, Assem M, Davila J, Strom S, Schuetz EG: PXR (NRII2): splice variants in human tissues, including brain, and identification of neurosteroids and nicotine as PXR activators. Toxicol Appl Pharmacol 2004, 199:25I-265.

21. Ravdin PM, Green S, Dorr TM, McGuire WL, Fabian C, Pugh RP, Carter RD, Rivkin SE, Borst JR, Belt RJ, Metch B, Osborne CK: Prognostic significance of progesterone receptor levels in estrogen receptor-positive patients with metastatic breast cancer treated with tamoxifen: results of a prospective Southwest Oncology Group study. J Clin Oncol 1992, I0:|284-I29|.

22. Cai Y, Konishi T, Han G, Campwala KW, French SW, Wan Y-JY: The role of hepatocyte $\mathbf{R X R}-\alpha$ in xenobiotic-sensing nuclear receptor-mediated pathways. Eur J Pharm Sci 2002, I5:89-96.

23. Masuyama $\mathrm{H}$, Hiramatsu $\mathrm{Y}$, Kodama J-I, Kudo T: Expression and potential roles of pregnane $X$ receptor in endometrial cancer. J Clin Endocrinol Metab 2003, 88:4446-4454.

24. Squires EJ, Sueyoshi T, Negishi M: Cytoplasmic localization of Pregnane X Receptor and ligand-dependent nuclear translocation in mouse liver. J Biol Chem 2004, 279:49307-493।4.

25. Kliewer SA, Umesono K, Mangelsdorf DJ, Evans RM: Retinoid X receptor interacts with nuclear receptors in retinoic acid, thyroid hormone and vitamin D3 signalling. Nature (Lond) 1992, 355:446-449.

26. Kliewer SA, Umesono K, Noonan DJ, Heyman RA, Evans RM: Convergene of 9-cis retinoic acid and peroxisome proliferator signalling pathways through heterodimers formation of their receptors. Nature (Lond) 1992, 358:77I-774.

27. Lawrence JA, Merino MJ, Simpson JF, Manrow RE, Page DL, Steeg PS: A high-risk lesion for invasive breast cancer, ductal carcinoma in situ, exhibits frequent overexpression of retinoid $X$ receptor. Cancer Epidemiol Biomarkers Prev 1998, 7:29-35.

28. Ariga N, Moriya T, Suzuki T, Kimura M, Ohuchi N, Sasano H: Retinoic acid receptor and retinoid $X$ receptor in ductal carcinoma in situ and intraductal proliferative lesions of the human breast. Jpn J Cancer Res 2000, 91: I 169-1 I76.

29. Suzuki T, Moriya T, Sugawara A, Ariga N, Takabayashi H, Sasano H: Retinoid receptors in human breast carcinoma: possible modulators of in situ estrogen metabolism. Breast Cancer Res Treat 200I, 65:3I-40.

30. Pratt WB, Toft DO: Steroid receptor interactions with heat shock proteins and immunophilin chaperones. Endocr Rev 1997, 18:306-360.

31. Zhan S-K, Lehmann J, Hoffmann B, Dawson MI, Cameron J, Graupner G, Hhermann T, Tran P, and Pfahl M: Homodimer formation of retinoid $X$ receptor induced by 9 -cis- retinoic acid. Nature (Lond) 1992, 358:587-591.

32. Crowe DL, Chandraratna AS: $\mathbf{A}$ retinoid $\mathbf{X}$ receptor $(\mathbf{R X R})$ selective retinoid reveals that $R X R$-alpha is potentially a therapeutic target in breast cancer cell lines, and that it potentiates antiproliferative and apoptotic responses to peroxisome proliferator-activated receptor ligands. Breast Cancer Res 2004, 6:R546-R555

33. Baum M, Houghton J, Riley D: Tamoxifen to prevent breast cancer. Lancet I99I, 338: II4

34. Dorssers LC, Flier S Van der, Brinkman A, van Agthoven T, Veldscholte J, Bems EM, Klijn JG, Beex LV, Foekens JA: Tamoxifen resistance in breast cancer: elucidating mechanisms. Drugs 2001, 61:172I-1733.

35. Clemons M, Danson S, Howell A: Tamoxifen ('Nolvadex'): a review. Cancer Treat Rev 2002, 28:165-180.

36. Crewe HK, Notley LM, Wunsch RM, Lennard MS, Gillam EM: Metabolism of tamoxifen by recombinant human cytochrome P450 enzymes: formation of the 4-hydroxy, 4'-hydroxy and $\mathbf{N}$-desmethyl metabolites and isomerization of trans-4hydroxytamoxifen. Drug Metab Dispos 2002, 30:869-874.

37. Desai PB, Nallani SC, Sane RS, Moore LB, Goodwin BJ, Buckley DJ, Buckley AR: Induction of cytochrome P450 3A4 in primary human hepatocytes and activation of the human pregnane $X$ receptor by tamoxifen and 4-hydroxytamoxifen. Drug Metab Dispos 2002, 30:608-612

38. Iscan M, Klaavuniemi T, Coban T, Kapucuoglu N, Pelkonen O, Raunio $\mathrm{H}$ : The expression of cytochrome $\mathbf{P 4 5 0}$ enzymes in human breast tumors and normal breast tissue. Breast Cancer Res Treat 200I, 70:47-54.

39. Modugno F, Knoll C, Kanbour-Shakir A, Romkes M: A potential role for the estrogen-metabolizing cytochrome P450 enzymes in human breast carcinogenesis. Breast Cancer Res Treat 2003, 82:191-197.

40. Sane RS, Buckley DJ, Buckley AR, Nallani SC, Desai PB: Role of human Pregnane $X$ Receptor in tamoxifen and 4-hydroxytamoxifen mediated CYP3A4 induction in primary human hepatocytes and LSI74T cells. Drug Metab Dispos . 2008 February 25 
4I. Synold TW, Dussault I, Forman BM: The orphan nuclear receptor SXR co-ordinately regulates drug metabolism and efflux. Nature Med 200I, 7:584-590.

\section{Pre-publication history}

The pre-publication history for this paper can be accessed here:

http://www.biomedcentral.com/1471-2407/8/174/pre pub

Publish with Bio Med Central and every scientist can read your work free of charge

"BioMed Central will be the most significant development for disseminating the results of biomedical research in our lifetime. " Sir Paul Nurse, Cancer Research UK

Your research papers will be:

- available free of charge to the entire biomedical community

- peer reviewed and published immediately upon acceptance

- cited in PubMed and archived on PubMed Central

- yours - you keep the copyright 